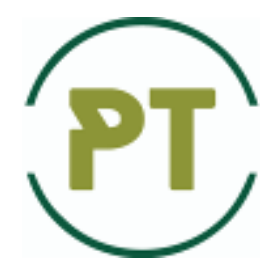

\title{
Evaluation of the wear of the duckfoot sweep cultivator blades and the technology of their hardening
}

\author{
T.S. Skoblo, I.M. Rybalko*, O.V. Nanka, O.V. Saychuk \\ Kharkiv Petro Vasylenko National Technical University of Agriculture, Kharkov, Ukraine \\ *E-mail: irybalko.ua@gmail.com
}

\begin{abstract}
In recent years, research and developments related to the creation of new areas using nanotechnology take a special place in scientific achievements. They are developed and widely used in Physics, Chemistry, Biology, Electronics, Medicine, Food Production and to a much lesser extent in Engineering. This is due to the fact that there are different requirements to parts and products used in mechanical engineering, they have a complex shape, are made of different materials, production methods, heat treatment. While operating, their working layer undergoes degradation with a significant change in structure and their hardening using nanocoatings may turn out to be ineffective in both technical and economic aspects. In this case, only a specific approach, which is determined by comprehensive research with identification of the main factors of parts damageability in specific production and operation conditions, can be expedient. In addition, in some cases for hardening, repair and restoration of parts it is expedient to use surfacing methods with the introduction of modifying agents in a liquid bath during crystallization. These modifying agents are nano-and dispersed diamonds, which make it possible to adjust temperature parameters of crystallization, grain size, and stress level. This approach allows using highalloyed, high-carbon electrodes even for thin-walled steel and cast iron products. In this case, the diamond inclusions additive plays the role of micro-refrigerators, which significantly change the crystallization temperature range. It is important to determine the optimal dose of the introduction of such a modifier and ensure uniform distribution the components in the coating. The presented work is devoted to the new technology development of hardening of cultivator blades metal with nano- and dispersed diamond additives, which are the part of the detonation charge from the disposal of ammunition. Nowadays, in agriculture, a large number of tillage implements are used for tillage, the working bodies of which are sweep blades. They are operated under conditions of abrasive particles impact, and this is accompanied by their intense wear with a corresponding change in the geometric dimensions of the main working surfaces. The worn sweep blades significantly reduce efficiency and quality of the carried-out work. The analysis of the effective choice of surfacing materials for hardening and improving their performance has been carried out and the nature of wear has been evaluated in order to identify areas of maximum damage and to determine the optimal method. It is known that T-590 and T620 electrodes are used for the restoration surfacing of tillage implements. It was found the hardfacing of thinwalled parts is accompanied by a smaller heat sink and, in some cases, they are flooded with defect formation. To reduce it, a non-magnetic fraction of detonation charge from ammunition disposal in the form of an electrode modification was introduced, which ensured the uniform distribution the components in the coating. The method of the X-ray electron-probe analysis has been used to evaluate features of structure formation and component distribution along the perimeter of the coating. It was found out that this method of hardening reduces heat input and increases the microhardness and wear resistance of the surfaced coating, reduces the transition zone and thermal impact. The recommended method of metal hardening of new cultivator blades is to apply stripes on the point tip and wings of blades. On the basis of the nature of wear, the expediency of applying stripes on the point tip of the cultivator blade from the front side, and on wings from the rear side, is justified. The optimal geometrical dimensions of hardening stripes and their location on the blade are presented, which allows minimizing the local stresses and increasing wear resistance.
\end{abstract}

Key words: cultivator blades, surfacing, detonation charge, stripes, heat input, modification, structure formation, nano- and dispersed diamonds. 


\section{Introduction}

The analysis of the literature revealed that about $60 \%$ of duckfoot sweep cultivator blades of agricultural machinery lose their working capacity due to the point tip and wings wear. In this case, the point tip wears out by $30 \mathrm{~mm}$, wings - by $15 \mathrm{~mm}$ in width. It is observed metal deformation in the working area of wings. Sufficiently a big number of methods for their reinforcing and repair were revealed. All of them are labor-consuming and after their use the resource of working bodies does not exceed $\sim 70 \%$ comparing to the new ones. Over time, while operating, the metal loses its original properties; its degradation takes place [1]. Worn parts restoration is not considered to be expedient since it is impossible to provide necessary properties simultaneously for all zones of the cultivator blade, taking into account its damage rate. Let us consider some ways to harden new duckfoot sweep cultivator blades.

There is the cultivator working body [2], which includes a duckfoot sweep blade, the working area of which is made in the form of a curved surface, and it passes from the beginning of its point tip to the end on side surfaces. While operating, the cultivator blade profile decreases in the direction of its movement and to preserve consumer properties, refractory metal stripes are formed by surfacing at different angles on its surface. Preliminary assessment of such technology of the cultivator working body blade reinforcing can be effective while operating due to the formation of a cogged profile while operating, which will provide self-sharpening. Such technology of increasing cultivator blades wear resistance is recommended to be used repeatedly during their operation and wear. The disadvantage of this reinforcing method is that stripes are applied only on the blade, which is formed by various methods (surfacing, machining work, plastic deformation, pull-off, etc.), which leads to accumulation of additional stresses in it and they are localized on the blade edge - blade base. Besides that, according to the studies, on the wings of the blades, the maximum wear takes place from their opposite surface, relatively to the blade of the point tip. Therefore, taking into account zones of the biggest wear and the reinforcing scheme adopted by the authors [2], it is impossible to achieve the self-sharpening effect. As for the recommendation regarding additional restorative blade reinforcing when using the equipment, according to this technology, it will also be ineffective. This is due to the fact that while operating the metal of the blade is subjected to wear (thickness decreases by $1 \ldots 1.5 \mathrm{~mm}$ ), which during application of stripes by surfacing will contribute to its penetration.

There is also known a method [3] of reinforcing the blade and adjacent to it perpendicularly directed zones of the cultivator blades by stripes surfacing with a wear-resistant material, and in the interstrip zones by creating rows of holes formed while stamping. Such technology is complex and accompanied by incompatible operations in the technological flow chart of production, which uses various approaches for applying holes by stamping and stripes by welding. The use of various technological processes will contribute to the localization of stresses from stripes surfacing by stamping zones, which will lead to the formation of defects and cracks at the holes. The method also does not prevent the deformation of the wings of the blades while operating.

The solution [4] may be more effective in terms of its technological essence and results, increasing service durability of duckfoot sweep cultivator blades. It is aimed at reducing blade wear by applying reinforcing stripes on both of its surfaces, forming a working surface.

The application of reinforcing stripes in this work was carried out according to a different scheme. It was carried out by local processing with a laser beam and this made it possible to apply reinforced stripes of infinitely small sizes on both surfaces of the blade. This treatment does not provide a significant increase in wear resistance because it does not use additional reinforcing by alloying, which can significantly increase the hardness. This method uses carbon steel reinforcing of cultivator blades only due to heat treatment of the shallow depth zones. This is due to the fact that the increase of heat input by this method will lead to crack formation and disruption of the product. This method also will not provide the increase of the blade wear resistance of the cultivator blade wings. In the considered technological solutions of reinforcing methods of duckfoot sweep cultivator blades, specific effective recommendations are also not provided for the parameters of the applied reinforcing stripes, the structure formation and properties achieved in reinforcement zones.

\section{Goal and problem statement}

The aim of the study was to develop a method of hardening of thin-walled cultivator blades by applying a programmed coating by hardfacing with a high-carbon alloyed electrode with modification of secondary raw materials for crushing the carbide phase, minimizing the transition zone and the tendency to form defects.

The goal of increasing consumer properties of the cultivator blades can be achieved by changing the reinforcing scheme and stable operation based on a statistical analysis of wear and deformation of such a product, with the subsequent possibility of reinforcing by surfacing with modifying and carbide-containing components of the electrode.

The use of such technology in production requires an innovative approach to obtain reinforcing stripes by electrode surfacing with minimization of stresses, as well as the formation of a metal structure without defects.

Earlier it was carried out some works on modifying by detonation charge from ammunition disposal when restoring parts of sufficient thickness [5, 6], when welding cracks in cast-iron body parts [7, 8]. It was found out that the introduction of secondary raw materials into a liquid bath while surfacing reduces heat input and creates 
favorable conditions for crystallization of various even non-technological high-carbon alloys. In this work, there was an equally challenging task of ensuring the application of high-quality reinforcing coatings on the thin cultivator blade, taking into account the nature of their wear and damage.

\section{Material and Methods}

A significant disadvantage of modern duckfoot sweep cultivators blades with plane deformers is poorquality soil loosening. The intensification of such an effect due to the cutting edges wear of the cultivator blades has a negative effect on the energetics of the treatment process. In addition, bioactive soil structures break down into dusty, easily subjected to erosion [9].

In this regard, it is of interest to conduct research on cultivator blades wear for new technological process development, which, on the one hand, increases their durability and, on the other hand, improves tillage quality.

Currently, there are no real physical and mathematical models of abrasive wear and formation of the geometry of cultivator blades cutting elements. Determination of the basic regularities of abrasive wear of cutting elements, formation of their optimal geometry, selection of materials for manufacturing and reinforcing, their influence on the technological process of production and operation is an important task in resource improving of tillage machine bodies $[10,11]$.

It was found out 10] that the process of interaction of machine working bodies with the soil while they are moving is characterized by the abrasive impact on a wedge with a plane or curvilinear working surface. Blade impact on the soil depends on the nature of material deformation, wedge parameters, physico-mechanical properties and condition of the metal, as well as the soil, the speed of machine movement.

Degree of blade abrasive wear in thickness can be represented as a function of the following factors:

$$
I_{h}=f\left(p, L, H_{\mu}, S\right)
$$

where $p$ is a normal specific dynamic pressure of the soil; $L$ is a friction path; $H_{\mu}$ is a blade material hardness; $t$ is an indicator of abrasive wear capacity; $S$ is a friction area.

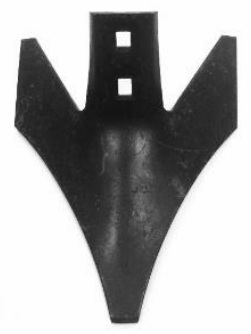

a

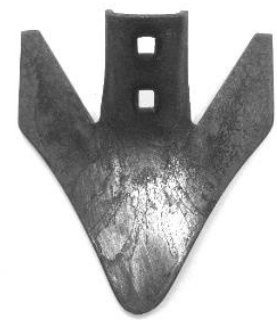

b

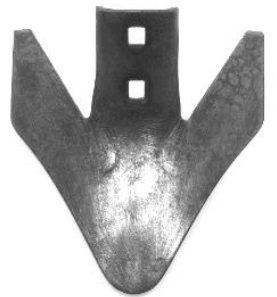

c

Fig. 1. Duckfoot sweep cultivator blade of MARATHON SERIES production of OSMUNDSON company: $a$ - new; $b, c$ - worn out

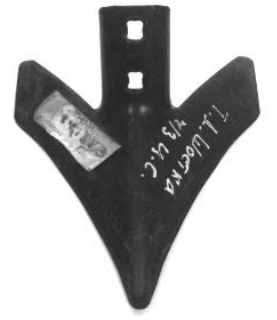

a

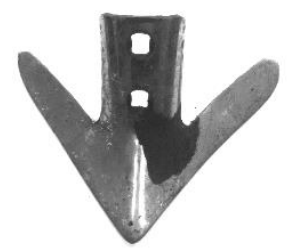

d

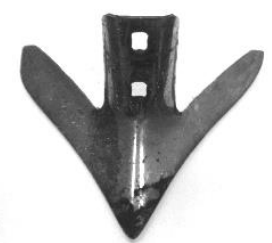

b

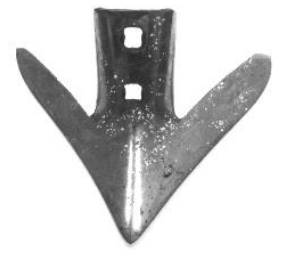

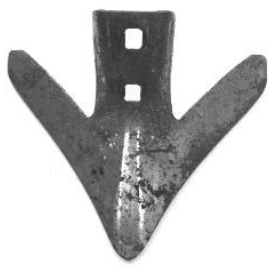

c

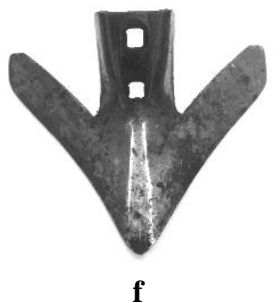



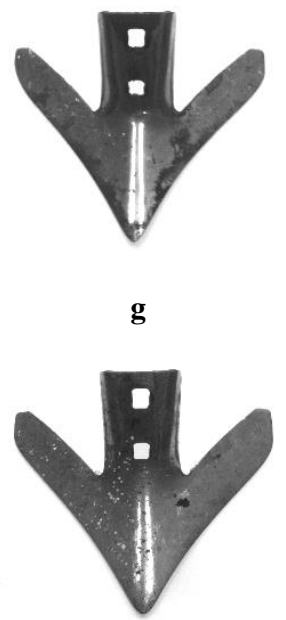

j

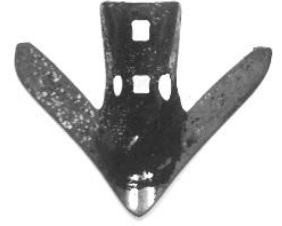

h

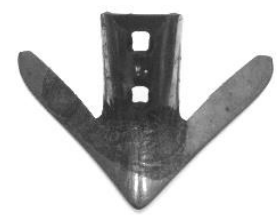

$\mathbf{k}$

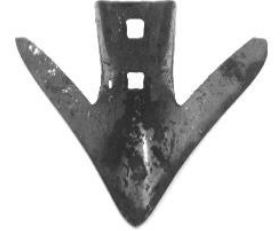

i

Fig. 2. Duckfoot sweep cultivator blade 9.3 "TigerMate II of CNH company:

$$
\text { a - new; }
$$

$$
\text { b - k - worn out }
$$

For the analysis of the profile change of duckfoot sweep cultivator blades in operation, products made by MARATHON SERIES of OSMUNDSON firm (Fig. 1) and 9.3 "TigerMate II of CNH firm (Fig. 2) were selected. Both new and used (worn out) under the same conditions (soils) of operation [12, 13] were comparatively studied.

The thickness and main dimensions of wings, grip were checked. Visually, it is seen that their geometrical dimensions differ significantly after operation. A ruler and Miol digital caliper were used to determine the thickness. Main characteristics: measurement accuracy $-0.01 \mathrm{~mm}$, measurement range $0-150 \mathrm{~mm}$. Blades were measured according to the developed scheme presented in Fig. 3.

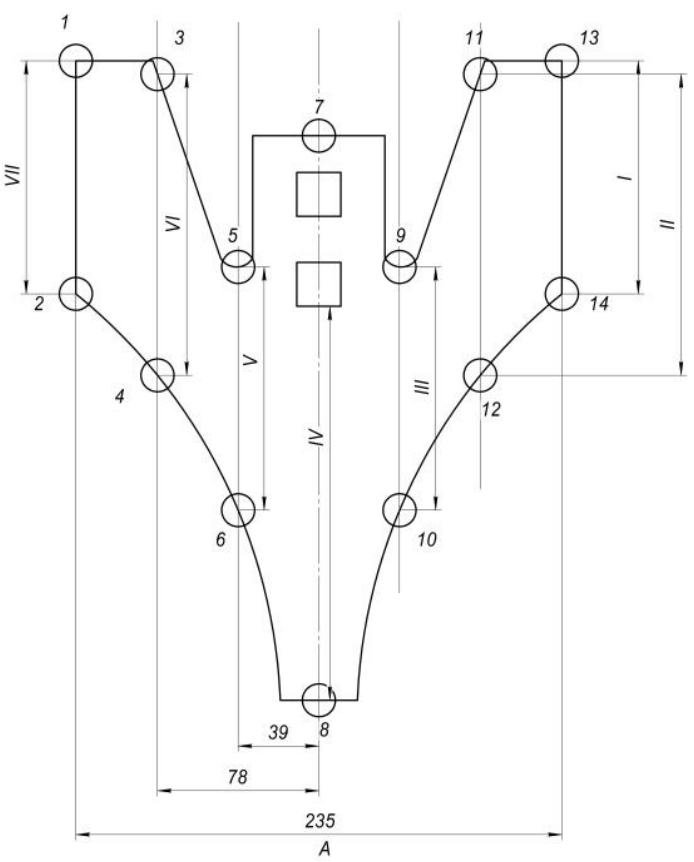

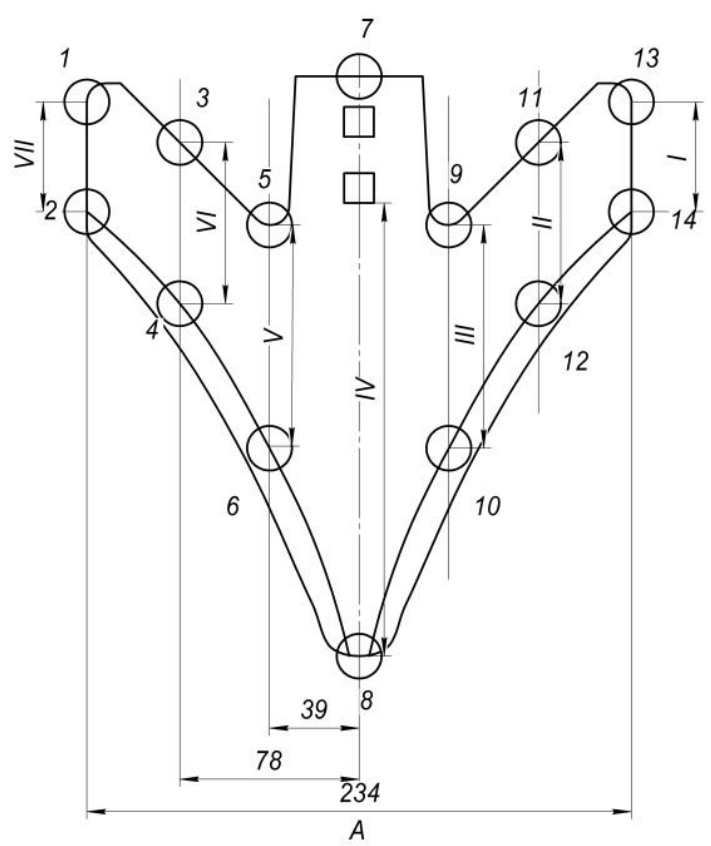

b

Fig. 3. Measurement of thickness and linear dimensions on new (a) and worn out (b) cultivator blades of MARATHON SERIES and TM II 9.3"

The circles indicate the thickness measurement points. The quality assessment of new cultivator blades showed that their geometrical dimensions are identical on both sides, and the thickness change is $5.43-6.09 \mathrm{~mm}$ for MARATHON SERIES and 6.34 - 7.33 for 9.3 "TigerMate II. 14 measurements were carried out on each blade. Grasp width of new blades of two different manufacturers was $235 \mathrm{~mm}$ and $234 \mathrm{~mm}$, respectively. Therefore, a blade was divided into three conditional zones from the center, through $39 \mathrm{~mm}$ each. Geometrical 
dimensions are indicated by Roman numerals — the dimensions of wings, point tip, which corresponded to 7 dimensions. These measurements were necessary to assess wear rate.

Further, grasp width was measured on worn blades - size A (see Fig. 3), the differences of which can be noticed visually. By the difference of indications of new and out-of-service blades, they were judged on their wear, as well as on the analysis of their combination (superposition).

\section{Results and Discussion}

On the basis of the proposed technique, the cultivator blades of both foreign and domestic production were analyzed (Fig. 4 - 7). While operating the blade width of MARATHON SERIES remained almost unchanged, and 9.3 "TigerMate II decreased from $234 \mathrm{~mm}$ to $227 \mathrm{~mm}$.

From the data obtained it follows that the cultivator blades do not wear evenly, the thickness in all areas of the analysis is different (Fig.4, 6). The dimensional characteristics of new blades are the same and symmetrical. After operation, they vary greatly (Fig.5, 7). This indicates that blades work in different conditions, soils and wear out unevenly. Skewness can be seen when fixing them on the rack of the cultivator. Some blades had visible abrasions (in the blade attachment zone) of the base metal, which indicated their long operating time and untimely replacement during maintenance or repair.

Wear of the cutting edges of cultivator blades is an irreversible process, during the interaction with the soil while operating. The size and nature of wear is determined, first of all, by stress pattern distribution on working surfaces of the cultivator blade [14].

To ensure cultivator blades durability, reduce the amount of their wear, it is necessary, on the one hand, to reduce the tendency to abrasive damage to the impact, and on the other hand, to improve the operational properties of the material by the technology and the type of applied reinforcing coatings.

Based on the experience of experts of Kharkiv Petro Vasylenko National Technical University of Agriculture, this may be most effective when using reinforcing with an optimal material and special modification. Experimental studies indicate that the greatest wear intensity of duckfoot sweep cultivator blades is typycal for the point tip. As moving away from it, the wear rate of the blade cutting edge decreases.

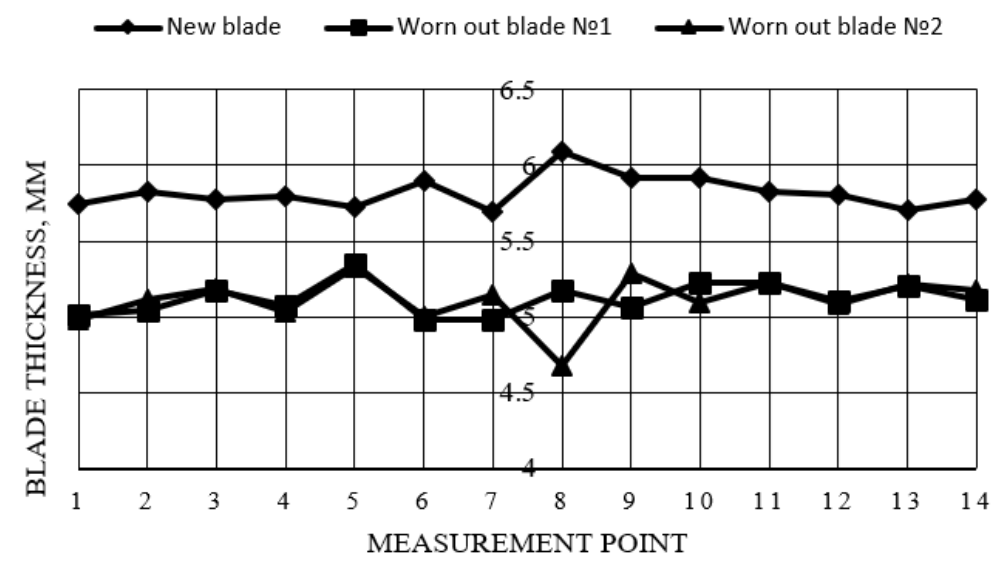

Fig. 4. Change in metal thickness of cultivator blades of MARATHON SERIES made in the USA while operating

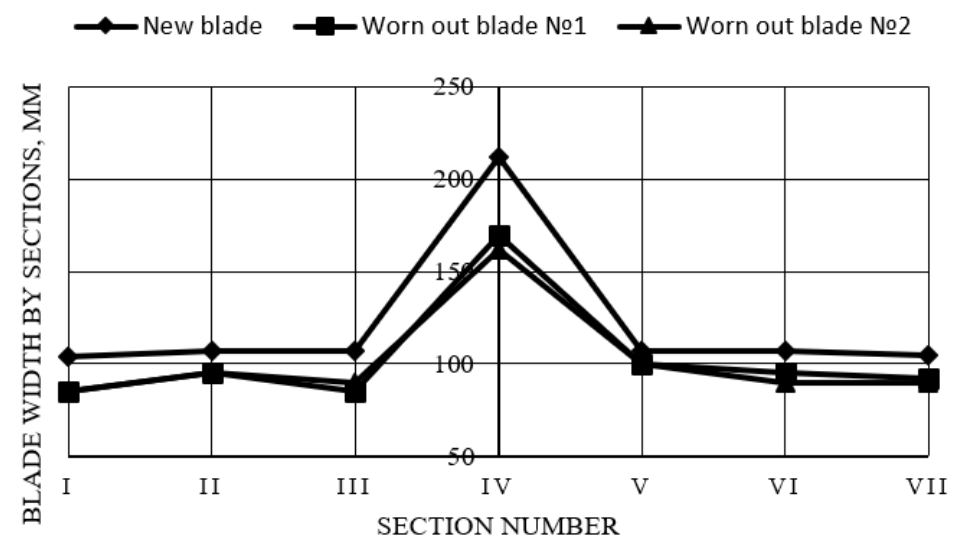

Fig. 5. Change of cultivator blades sizes

of MARATHON SERIES made in the USA by sections (see. Fig. 3) 

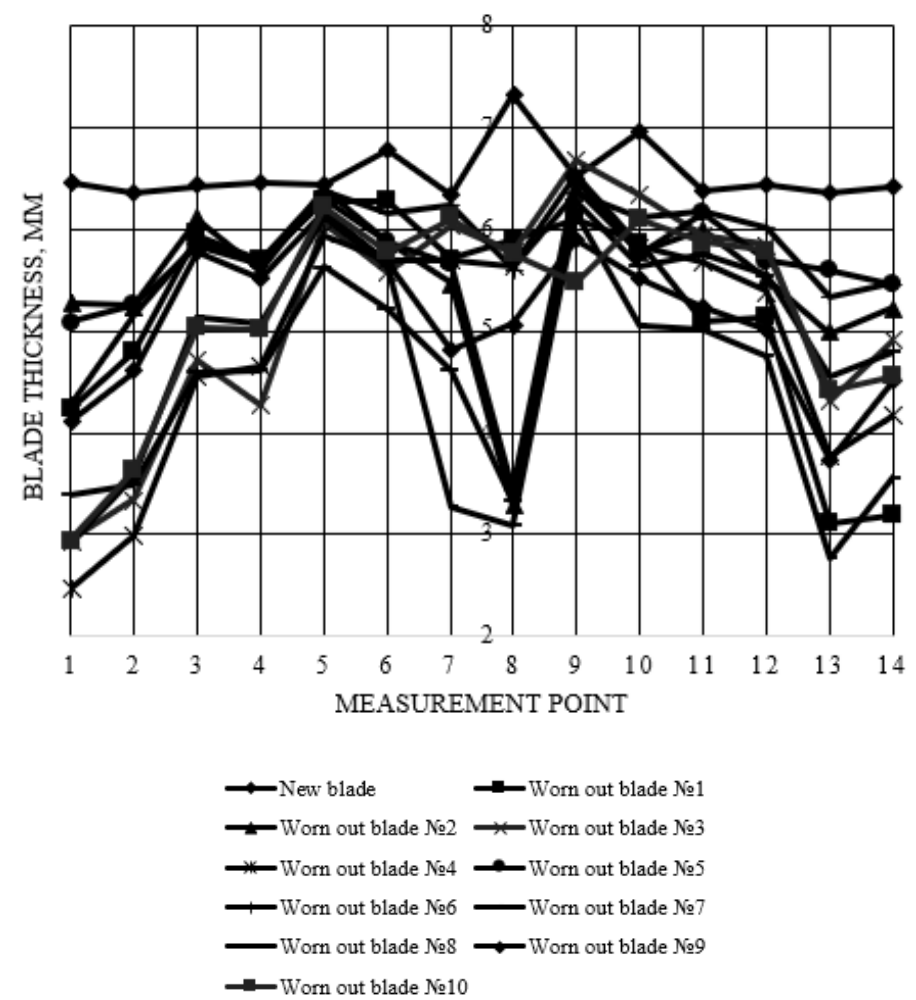

Fig. 6. Change in metal thickness of cultivator blades of 9.3 "TigerMate II made in Canada while operating (according to Fig. 3)

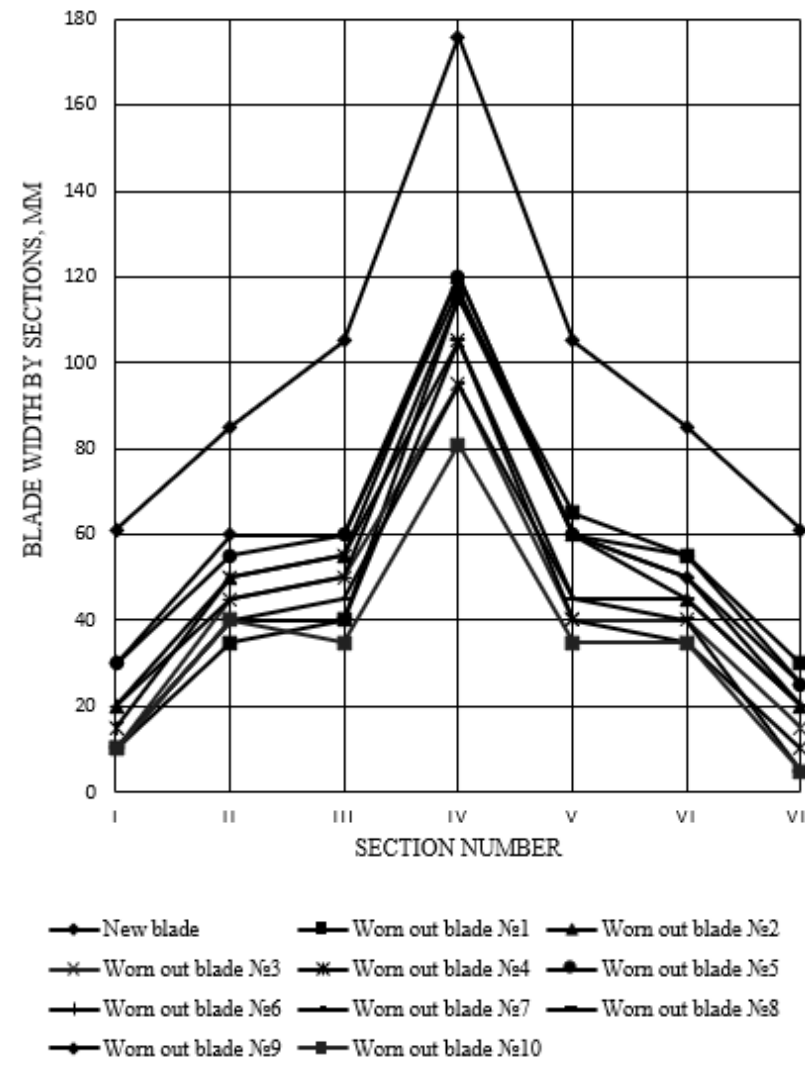

Fig.7. Changing cultivator blades sizes of 9.3 "TigerMate II made in Canada by sectional zones (according to Fig. 3)

The pattern of wear intensity change of the blade along the length of its cutting edge, presented in works $[9,10]$, has the form: 


$$
i=i_{o} m_{i} l^{-\frac{H_{\mu} X}{H_{a}} \sqrt{\frac{E_{M} S}{p T}} l}
$$

where $H_{\mu}$ and $H_{a}$ - hardness values of blade material and abrasive, respectively;

$X$ - an empirical constant, taking into account optimal factors;

$E_{M}$ - a coefficient of blade material elasticity;

$S-$ an area of the blade working surface;

$p$ - a specific load of the soil on the blade;

$T$ - an operating time on one blade;

$L-$ - a length of the section of reservoir;

$i$ - a wear rate.

The proposed dependence of wear rate along the cutting edge length shows that the uneven wear of the cultivator blades can be explained by the varying pressure of the soil on different zones around the perimeter.

Having studied the nature of cultivator blades wear, a new method of their reinforcing along the working surface perimeter was proposed [15]. The method consists in surfacing wear-resistant stripes on the blade surface with the introduction of modifying agents with nano- and dispersed diamonds. Stripes on duckfoot sweep cultivator blade were formed according to Fig. 8, taking into account intensity and nature of its wear. According to the nature of wear, into point tip stripes with the size of $20 \mathrm{~mm}$, and wings with the thickness of 12-15 mm with the distance of at least $10 \mathrm{~mm}$ between them will be formed by the reinforcing coating in order to prevent the length overlapping of heat-affected zones.

The optimal stripe sizes are determined from the conditions of the stress state formation during electrode surfacing, as well as by the coating quality and the tendency of the metal to damage during reinforcing. It is important to take into account, stresses appearing in the cutting edges and the transition zone of the blade base, wings while operating. Taking into account the maximum wear and wings deformation, reinforcing stripes in these zones were applied from the opposite surface relatively to the point tip (see Fig. 8).

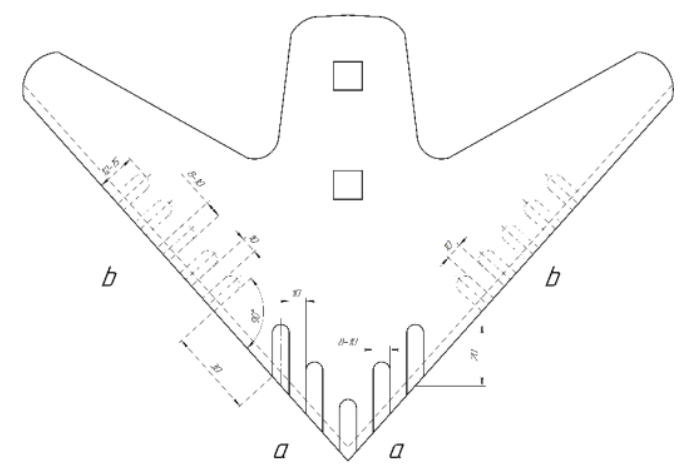

Fig.8. The scheme of reinforcing stripes surfacing on a duckfoot sweep cultivator blade surface (see Fig. 1,a, 2, a):

$$
\begin{gathered}
\text { a - point tip; } \\
\text { b - wings }
\end{gathered}
$$

The possibility of using reinforcing surfacing to create stripes with T-620 carbide-containing electrode, which contains, \%: 3,0 C, 2,2 Si, 1,2 Mn, 22,5 Cr, 0,7 Ti, 0,8 B, 0,03 S was studied. Such an electrode provides maximum penetration of the cultivator blade with the thickness of $6 \mathrm{~mm}$ to its depth up to $3 \mathrm{~mm}$ without defects when modifying it with a coating of non-magnetic component of the detonation charge obtained from the ammunition disposal. Such a charge, according to the chemical analysis, includes nano- and dispersed diamonds, and graphite (a small fraction) $3.37-3.43 \% \mathrm{C}$, as well as copper (up to $3.14 \%$ ) and iron (up to $2.9 \%$ ) [16].

Previous studies [15] showed that the optimal share of the modifying additive is $6-8 \%$. For uniform entry into a liquid bath, it was used as an electrode coating. Current strength $160 \mathrm{~A}$ and voltage $28 \mathrm{~V}$ were used as the hardening parameters.

Application of the reinforcing technology to a small depth by stripes surfacing provides a high-quality reinforcing coating and fusion zone with minimal heat input due to the micro-refrigerators creation - inclusions of dispersed diamonds that do not dissolve in the liquid bath, but significantly reduce its temperature (by 250 $300{ }^{\circ} \mathrm{C}$ ). This reduces the grain size by $20 \%$, the heat-affected zone by $40 \%$ and stress, and also increases the anisotropy of the structure in the applied reinforcing stripes not only on the cutting edge, but also in the base metal. The anisotropy of the structure in such a built-up metal is $0.95-0.97$. These properties provide the operational durability increase due to the absence of the tendency of the metal to crack formation in the heataffected zone of surfacing when stripes are applied. 


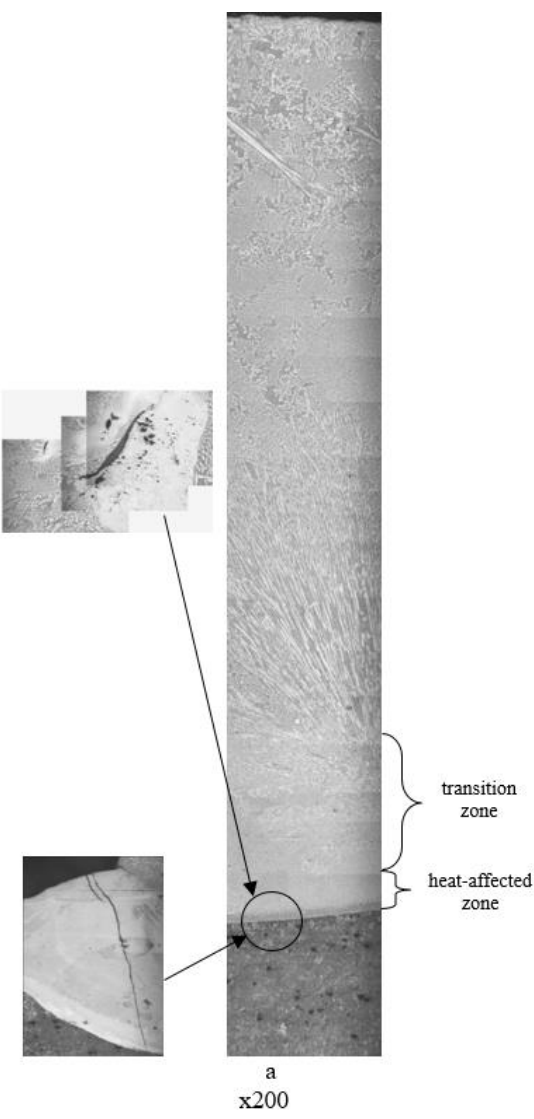

a

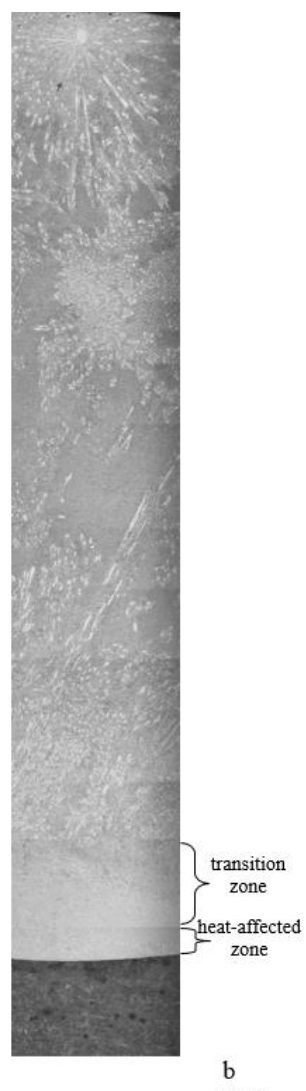

Fig.9. Microstructure over the section of samples:

a - surfacing with T-620 electrode;

b - surfacing with T-620 electrode

with non-magnetic fraction modification of the detonation charge

Fig. 9 comparatively shows the formed structures during surfacing without modifying by secondary charge (a), which were accompanied by crack formation in the varying thickness blade-base area, as well as in another blade part, and (b) using a modifying agent, which was previously applied on the surface of electrodes $\varnothing$ $4,0 \mathrm{~mm}$ with charge proportion of $6.0-8.0 \%$ [15]. When forming stripes, a current of $150-180 \mathrm{~A}$ was used, the deposition rate was $17-19 \mathrm{~m} / \mathrm{h}$.

Besides identified defects (pores, cavities and cracks), it should be noted that in the area of reinforcing stripes application a more heterogeneous structure is formed with the formation of zones of coarse, thin, and extended carbide sockets near the fusion boundary, which is characterized by increased microhardness.

When modifying, such carbide sockets are more evenly distributed in the metal matrix, and they differ in structure. Instead of extended thin inclusions, they are fragmented, what contributes to the formation of a more homogeneous structure, less stress state of the transition zone, as well as its length decrease. In this transition layer, there are no defects at all.

Distribution of chemical components along the depth of the surfaced stripe in accordance with two options - without and with the use of a modifying agent was locally estimated by X-ray electron probe analysis (XREPA) (Fig. 10 and 11, Table 1 and 2).

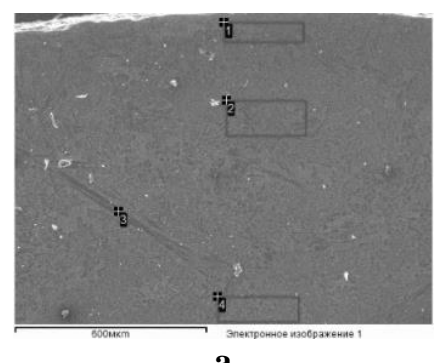

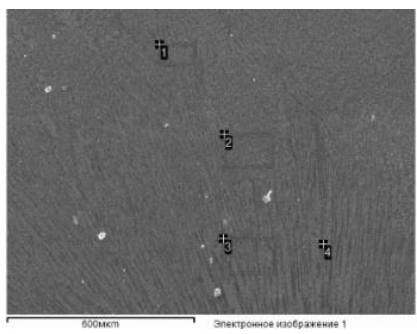

$\mathbf{b}$

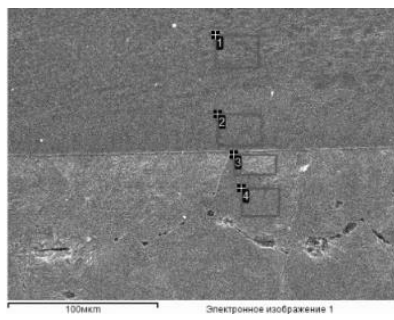

c

Fig.10. Electronic photographs of the structure of the surfaced stripes with T-620 electrode indicating XREPA zones: a - surfacing surface; b - middle;

c - heat-affected zone 


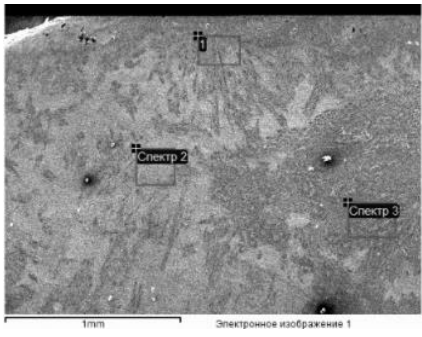

a

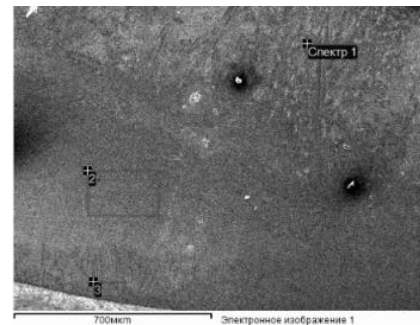

b

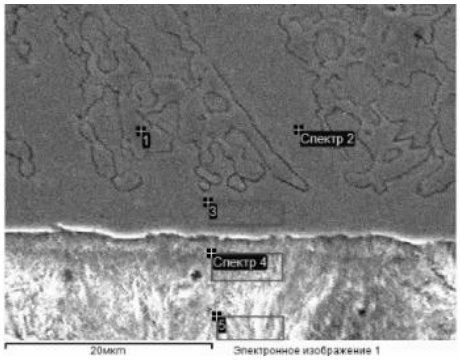

c

Fig.11. Electronic photographs of the structure of the surfaced stripes with T-620 electrode with a non-magnetic fraction modification of the detonation charge indicating XREPA zones: a - surfacing surface; $b$ - middle; $c$ - heat-affected zone

When modifying metal surfacing in the stripe, the temperature of the liquid bath decreases (the presence of micro-refrigerators - diamonds) and the crystallization conditions change [17]. This is accompanied by increase in the average share of the carbide phase by $27 \%$ in the upper zone, in the middle by - $32 \%$ and transitional $-70 \%$. Besides that, the homogeneity of the distribution of carbon-bearing phases in surfaced stripes is more uniform across the section during the modification with the secondary charge. Thus, during conventional surfacing, carbon concentration in the upper zone varies within $2.8 \%$, the middle is $1.83 \%$, and the transition one is $1.64 \%$. In the case of modification, there is a large homogeneity in the distribution of this component in various zones. This corresponds to the achieved microhardness level. With the conventional method of surfacing there is a significant proportion of oxygen in all zones of analysis up to $1.6-3.39 \%$. When modifying with the secondary charge (see Table 2), this component was singly detected only in the upper zone of the stripe $(2.28 \%)$.

As for the distribution of $\mathrm{Mn}, \mathrm{Si}$, Mo components, they are close in concentration in comparable variants. Regarding the proportion of iron, its average value is $8.4 \%$ more when modifying, and in the upper and middle zones it differs even more significantly - by $14.5 \%$. The observed can be explained by the formation in these zones of a larger amount of cementite-type carbides.

Table 1

\section{XREPA data on the distribution of chemical elements over the section of the deposited stripes with T-620 electrode, \%}

Surface

\begin{tabular}{|c|c|c|c|c|c|c|c|c|c|}
\hline Spectrum & $\mathrm{C}$ & $\mathrm{O}$ & $\mathrm{Al}$ & $\mathrm{Si}$ & $\mathrm{Cr}$ & $\mathrm{Mn}$ & $\mathrm{Fe}$ & $\mathrm{Zr}$ & $\mathrm{Mo}$ \\
\hline 1 & 8.71 & 3.15 & 0.51 & 1.69 & 22.24 & 5.38 & 55.47 & 0.34 & 2.50 \\
\hline 2 & 8.91 & 2.78 & 0.19 & 1.48 & 24.05 & 4.96 & 54.61 & 0.86 & 2.15 \\
\hline 3 & 10.51 & - & - & 0.05 & 42.71 & 5.49 & 39.47 & - & 1.77 \\
\hline 4 & 7.71 & 2.52 & 0.17 & 1.60 & 23.35 & 5.34 & 56.83 & 0.84 & 1.64 \\
\hline Max & 10.51 & 3.15 & 0.51 & 1.69 & 42.71 & 5.49 & 56.83 & 0.86 & 2.50 \\
\hline Min & 7.71 & 2.52 & 0.17 & 0.05 & 22.24 & 4.96 & 39.47 & 0.34 & 1.64 \\
\hline
\end{tabular}

Middle

\begin{tabular}{|c|c|c|c|c|c|c|c|c|c|c|}
\hline Spectrum & $\mathrm{C}$ & $\mathrm{O}$ & $\mathrm{Al}$ & $\mathrm{Si}$ & $\mathrm{Ca}$ & $\mathrm{Cr}$ & $\mathrm{Mn}$ & $\mathrm{Fe}$ & $\mathrm{Zr}$ & $\mathrm{Mo}$ \\
\hline 1 & 8.05 & 2.42 & 0.23 & 1.53 & 0.18 & 24.24 & 5.75 & 54.81 & 0.81 & 1.98 \\
\hline 2 & 7.60 & 2.37 & 0.29 & 1.60 & & 22.85 & 5.55 & 57.03 & 0.36 & 2.37 \\
\hline 3 & 7.69 & 1.60 & 0.29 & 1.55 & 0.09 & 24.04 & 5.53 & 56.86 & 0.34 & 2.02 \\
\hline 4 & 9.43 & & & & & 42.95 & 5.19 & 41.00 & & 1.43 \\
\hline Max & 9.43 & 2.42 & 0.29 & 1.60 & 0.18 & 42.95 & 5.75 & 57.03 & 0.81 & 2.37 \\
\hline Min & 7.60 & 1.60 & 0.23 & 1.53 & 0.09 & 22.85 & 5.19 & 41.00 & 0.34 & 1.43 \\
\hline
\end{tabular}

\begin{tabular}{|c|c|c|c|c|c|c|c|c|c|}
\hline \multicolumn{10}{|c|}{ Transition zone } \\
\hline Spectrum & $\mathrm{C}$ & $\mathrm{O}$ & $\mathrm{Al}$ & $\mathrm{Si}$ & $\mathrm{Cr}$ & $\mathrm{Mn}$ & $\mathrm{Fe}$ & $\mathrm{Zr}$ & Mo \\
\hline 1 & 7.14 & & 0.26 & 1.60 & 21.96 & 5.35 & 61.26 & 0.29 & 2.14 \\
\hline 2 & 7.01 & 2.30 & - & 1.27 & 13.91 & 3.90 & 70.29 & - & 1.32 \\
\hline 3 & 6.65 & 3.39 & 0.17 & 0.19 & 0.28 & 0.99 & 88.32 & - & - \\
\hline 4 & 5.55 & 2.11 & - & 0.17 & - & 0.92 & 91.24 & - & - \\
\hline Max & 7.14 & 3.39 & 0.26 & 1.60 & 21.96 & 5.35 & 91.24 & 0.29 & 2.14 \\
\hline Min & 5.55 & 2.11 & 0.17 & 0.17 & 0.28 & 0.92 & 61.26 & 0.29 & 1.32 \\
\hline
\end{tabular}




\section{XREPA data on the distribution of chemical elements over the section of the deposited stripes with T-620 electrode with modification of a non-magnetic fraction of the detonation charge, $\%$}

\begin{tabular}{|c|c|c|c|c|c|c|c|c|}
\hline \multicolumn{9}{|c|}{ Surface } \\
\hline Spectrum & $\mathrm{C}$ & $\mathrm{O}$ & $\mathrm{Al}$ & $\mathrm{Si}$ & $\mathrm{Cr}$ & $\mathrm{Mn}$ & $\mathrm{Fe}$ & Mo \\
\hline 1 & 12.98 & 2.28 & 0.22 & 1.17 & 17.05 & 3.90 & 61.12 & 1.27 \\
\hline 2 & 10.78 & & & 1.28 & 18.19 & 4.12 & 64.15 & 1.47 \\
\hline 3 & 14.06 & & 0.59 & 1.37 & 19.13 & 4.23 & 58.61 & 2.01 \\
\hline Max & 14.06 & 2.28 & 0.59 & 1.37 & 19.13 & 4.23 & 64.15 & 2.01 \\
\hline Min & 10.78 & 2.28 & 0.22 & 1.17 & 17.05 & 3.90 & 58.61 & 1.27 \\
\hline
\end{tabular}

\begin{tabular}{|c|c|c|c|c|c|c|c|}
\hline \multicolumn{9}{|c|}{ Middle } & Mo \\
\hline Spectrum & C & Al & Si & Cr & Mn & Fe & Mo \\
\hline 1 & 13.12 & & 1.39 & 18.58 & 4.19 & 61.07 & 1.65 \\
\hline 2 & 9.28 & 0.47 & 1.45 & 17.06 & 3.79 & 66.54 & 1.41 \\
\hline 3 & 9.23 & & 1.30 & 15.47 & 3.60 & 68.80 & 1.60 \\
\hline Max & 13.12 & 0.47 & 1.45 & 18.58 & 4.19 & 68.80 & 1.65 \\
\hline Min & 9.23 & 0.47 & 1.30 & 15.47 & 3.60 & 61.07 & 1.41 \\
\hline
\end{tabular}

\begin{tabular}{|c|c|c|c|c|c|c|}
\hline \multicolumn{7}{|c|}{ Transition zone } \\
\hline Spectrum & $\mathrm{C}$ & $\mathrm{Si}$ & $\mathrm{Cr}$ & $\mathrm{Mn}$ & $\mathrm{Fe}$ & Mo \\
\hline 1 & 13.61 & 0.55 & 23.14 & 3.66 & 57.77 & 1.27 \\
\hline 2 & 10.78 & 1.39 & 7.88 & 2.72 & 77.24 & \\
\hline 3 & 9.82 & 1.20 & 16.30 & 3.28 & 68.62 & 0.78 \\
\hline 4 & 8.06 & 0.98 & 5.79 & 2.28 & 82.89 & \\
\hline 5 & 11.20 & 0.24 & 0.46 & 1.11 & 86.98 & \\
\hline Max & 13.61 & 1.39 & 23.14 & 3.66 & 86.98 & 1.27 \\
\hline Min & 8.06 & 0.24 & 0.46 & 1.11 & 57.77 & 0.78 \\
\hline
\end{tabular}

Chromium distribution over the three analyzed zones is 2.2 times more uniform when using modifying with stripes application by surfacing, which is achieved by carbide phases crushing during crystallization.

Insignificant tendency of $\mathrm{Al}$ increase during the modification can be explained by the fact that this component is part of the detonation charge. It was revealed that its share in different surfacing zones (upper, middle) varies within $0.17-0.51 \%$ at conventional stripes surfacing and - within $0.22-0.59 \%$ in the case of modifying with a secondary charge.

The absence of difference in the content of $\mathrm{Al}$ and $\mathrm{Si}$ components can be related to the concentration change of these components, taking into account that with conventional application of stripes by surfacing, base metal inclusions emerge to the coverage area, and when modifying, they are a part of the modifier and their share in it is not stable.

Wearing tests were carried out on SMT-1 friction machine at State Enterprise V.A. Malyshev Plant.

The relative wear resistance of various reinforcing methods of parts surfaces was carried out and evaluated according to three variants [17]:

1 - source material of a cultivator blade steel $65 \mathrm{G}$;

2 - surfacing with T-620 electrode with modification by a non-magnetic fraction of the detonation charge;

3 - surfacing with T-620 electrode.

Tests were carried out according to "disc-block" scheme. Tests of samples in the abrasive medium of quartz sand without lubrication were carried out according to Brinell scheme. Samples 10x10 mm in size, cut from the surfacing zone and processed on a surface grinder with a load of $5 \mathrm{~kg}$, were subjected to testing. Counterbody - PTFE-4 - Fluoroplastic. In this test, fluoroplastic was used as a body to hold abrasive in the friction area. The sand from the Staroverovsky deposit (Ukraine) with a fraction of 0.25-0.4 mm was used as an abrasive. Before testing, the prepared samples (blocks, discs) were washed, marked, weighed on a WA-200 scales.

Test results are shown in Table. 3. The friction path was $100 \mathrm{~m}$.

Table 3

Abrasion tests

\begin{tabular}{|c|c|c|}
\hline No./no. & Reinforcing option & Wear, $\mathrm{g}$ \\
\hline 1 & Source material of cultivator blade steel 65G & 0.0145 \\
\hline 2 & Surfacing with T-620 electrode & 0.0090 \\
\hline 3 & $\begin{array}{c}\text { Surfacing with T-620 electrode with modification by a non-magnetic fraction of } \\
\text { the detonation charge }\end{array}$ & 0.0044 \\
\hline
\end{tabular}


The proposed reinforcing method of cultivator blades is recommended for stable operation of equipment by minimizing the creation of local stresses, which ensures the absence of defects, as well as while operating improvement of the working tool stability (excludes the deformation of the wings) and in 3 times increases wear resistance comparing to the product source material or reinforcing without modification.

Experiments were carried out by comparing 81 pieces of two types of cultivator blades in one installation of the Tiger Mate II cultivator - 66 pieces without hardening and 15 hardened pieces, proposed by the method, which showed on average that their wear is much less, regardless of their location and decreases 2.3 times, which almost corresponds to bench tests. The tests were carried out in PE "Agrarian Investments" of the Sumy region, Ukraine.

\section{Conclusions}

1. A new solution is presented for a constructive approach to reinforcing cultivator blades without deformation and with the use of secondary raw material modifi-cation from the ammunition disposal with a nonmagnetic fraction of the detona-tion charge, which makes it possible to use a high-carbon alloyed electrode metal.

2. As a result of the carried out research, a new reinforcing method of cultivator blades was developed and proposed. The method consists in applying reinforc-ing stripes on the point tip from the front side of the blade and on its wings from the back. According to the analysis of wear processes, it is optimal to apply reinforcing stripes on the point tip of $20 \mathrm{~mm}$ in size and 12 to $15 \mathrm{~mm}$ on the wings with a distance of at least 10 $\mathrm{mm}$ between them to prevent overlapping of the heat-affected zones.

3. When reinforcing stripes are surfaced with carbide-containing T-620 electrode, research were carried out on the possibility of using for modification non-magnetic fraction of the detonation charge from the ammunition disposal in the form of electrode coating. To control liquid bath temperature, the proportion of introduced modifier was optimized. It was found out that this combination of blade materials and reinforcing stripes allows to reduce heat input, improve sur-facing quality (ensure coarse carbides crushing), increase hardness and wear resistance by 2 and 3 times comparing to the initial state and reinforcing without modifying additions, respectively, and also to eliminate defects formation when reinforcing quite a thin working tool.

\section{References}

1. Skoblo T.S., Sidashenko A.I., Rybalko I.N., Marchenko A.Yu., Tikhonov A.V. (2018): Assessment of the degree of metal degradation of products during operation. Technical service of agriculture, forestry and transport systems, 11: 49-59. (in Russian).

2. Volyk B.A., Tereshchenko M.V., Puhach A.M. (2008): The working body of the cultivator. Patent UA, Int. Cl. No. 85100. (in Ukrainian).

3. Kobets A.S., Volyk B.A., Kobets O.M., Havryl'chenko O.S., Sokol S.P., Puhach A.M. (2008): The working body of the cultivator. Patent UA, Int. Cl. No. 37351. (in Ukrainian).

4. Kobets A.S., Volyk B.A., Kobets O.M., Havryl'chenko O.S., Sokol S.P., Puhach A.M. (2007): The working body of the cultivator. Patent UA, Int. Cl. No. 25889. (in Ukrainian).

5. Markov A.V. (2015): Increasing the operational durability of agricultural engineering parts using secondary raw materials. Agrotechnics and energy supply, 5, 9: 12-25. (in Russian).

6. Markov A.V. (2015): The use of secondary raw materials and modifying additives to improve the performance of products. Bulletin of the Kharkiv Petro Vasylenko National Technical University of Agriculture, 158: 162-176. (in Russian).

7. Skoblo T.S., Sidashenko A.I., Saychuk A.V., Belkin E.L. (2017): Efficient technology for restoring body parts made of gray cast iron by welding defects. Welding production. 12, 997: 33-39. (in Russian).

8. Skoblo T.S., Sidashenko O.I., Saychuk O.V., Rybalko I.M., Radchenko O.O., Manilo V.L., Bantkovs'kyy V.A., Markov O.V. (2017): The way to improve the quality of the recovery of thin-walled products of gray iron. Patent UA, Int. Cl. No. 114590. (in Ukrainian).

9. Semchuk G.I. (2013): Dynamics of wear of cultivator paws. Technological audit and production reserves, 6/5: 27-28. (in Russian).

10. Zayika P.M. (2001): The theory of agricultural machines. Kharkiv, Oko. (in Ukrainian).

11. Severinov M.M. (1972): Wear parts of agricultural machinery. L., Kolos. (in Russian).

12. Skoblo T.S., Tikhonov A.V., Rybalko I.N., Kartashov S.G., Saychuk A.V., Kholkina I.V. (2015): Technology for the restoration of worn out cultivator tines of the MARATHON SERIES type by OSMUNDSON. Bulletin of the Kharkiv Petro Vasylenko National Technical University of Agriculture, 158: 188-197. (in Russian).

13. Rybalko I.N. (2016): Development of a methodology for assessing cultivator paws and their condition after operation. Bulletin of the Kharkiv Petro Vasylenko National Technical University of Agriculture, 168: 4651. (in Russian).

14. Skoblo T., Rybalko I., Tihonov A., Maltsev T. (2020): Evaluation of the stress state of a cultivator 
blade in production and operation. Res. Agr. Eng., 66: 60-65. https://doi.org/10.17221/8/2020-RAE

15. Skoblo T.S., Sidashenko O.I., Rybalko I.M., Tikhonov O.V., Oleinyk O.K. (2018): The way to improve the wear resistance of a duckfoot sweep cultivator blade. Patent UA, Int. Cl. No. 130824. (in Ukrainian).

16. Skoblo T.S., Nanka O.V., Sidashenko O.I., Kuskov Yu.M., Saychuk O.V., Romanyuk S.P., Markov O.V., Samson Yu.V. (2019): Method of obtaining a detonation mixture with a diamond fraction. Patent UA, Int. Cl. No. 138685. (in Ukrainian).

17. Narita K. (1969): The crystal structure of non-metallic inclusions in steel. M., Metallurgiia. (in Russian).

18. Skoblo T.S., Rybalko I.N., Tihonov A.V., Maltsev T.V. (2019b): Improving the wear resistance of hoe blades by modifying of restoration coatings. Problems of Tribology, 94, 4: 27-31. DOI: https://doi.org/10.31891/2079-1372-2019-94-4-27-32 
Скобло Т.С., Рибалко І.М., Нанка О.В., Сайчук О.В. Оцінка зносу стрілчастих лап культиватора і технологія їх зміцнення.

В останні роки особливе місце в наукових досягненнях займають розробки, пов'язані зі створенням нових напрямків 3 використанням нанотехнологій. Вони розвиваються i широко використовуються у фізиці, хімії, біології, електроніці, медицині, харчовому виробництві і значно меншою мірою в машинобудуванні. Це пов'язано з тим, що до деталей і виробів, що використовуються в машинобудуванні, пред'являються різні вимоги, вони мають складну форму, виготовляються з відмінних матеріалів, способів виробництва, термообробки. В процесі експлуатації їх робочий шар піддається деградації з істотною зміною структури і їх зміцнення з використанням нанопокриттів може виявитися, як в технічному, так економічному аспектах неефективним. У цьому випадку доцільним може бути тільки конкретне рішення, яке визначається всебічними дослідженнями з виявленням основних факторів пошкоджуваності деталей в конкретних умовах виробництва і експлуатації. Крім того, в ряді випадків для зміцнення, ремонту та відновлення деталей доцільно використовувати методи наплавлення 3 введенням модифікують присадок в рідку ванну при кристалізації. До числа таких присадок слід віднести нано- та дисперсні алмази, які дозволяють коригувати температурні параметри кристалізації, величину зерна, рівень напружень. Такий підхід дозволяє використовувати і високолеговані, високовуглецеві електроди навіть для тонкостінних виробів із сталей і чавунів. В цьому випадку присадка шихти з алмазною фракцією відіграє роль мікрохолодильників, які суттєво змінюють температурний інтервал кристалізації. Важливим $\epsilon$ визначити оптимальну дозу введення такого модифікатора та забезпечити рівномірний розподіл компонентів у покритті. Представлена робота присвячена розробці нової технології зміцнення металу стрілчастих лап культиватора нано- та дисперсними домішками алмазів, які входять до складу детонаційної шихти від утилізації боєприпасів. В даний час в сільському господарстві для обробки грунту використовується велика кількість грунтообробних знарядь, з робочими органами яких є стрілчасті лапи. Вони експлуатуються в умовах впливу абразивних частинок, та це супроводжується їх інтенсивним зносом 3 відповідною зміною геометричних розмірів основних робочих поверхонь. Зношені стрілчасті лапи значно знижують ефективність і якість виконуваних робіт. Проведено аналіз ефективного вибору наплавлювального матеріалу для зміцнення та підвищення їх працездатності і оцінено характер зносу, щоб виявити і зони максимальної пошкоджуваності, а також визначити оптимальний спосіб зміцнення. Відомо, що для відновлювального наплавлення грунтообробних знарядь застосовують електроди Т-590, Т-620. Встановлено, що наплавлення тонкостінних деталей супроводжується меншим тепловідводом та вони в ряді випадків проплавляються з формуванням дефектів. Для його зниження вводили не магнітну фракцію детонаційної шихти від утилізації боєприпасів у вигляді модифікування електрода, що забезпечувало рівномірний розподіл компонентів у покритті. Методом мікрорентгеноспектрального аналізу оцінено особливості структуроутворення і розподілу компонентів при такій технології зміцнення по перетину покриття. Встановлено, що даний спосіб зміцнення знижує тепловкладення й підвищує мікротвердість і зносостійкість наплавленого покриття, зменшує перехідну зону й термічного впливу. Рекомендований спосіб зміцнення металу нових лап культиватора полягає в нанесенні смуг на носок і крила лап. На основі характеру зносу обгрунтовано доцільність нанесення смуг на носок лапи культиватора 3 лицьового боку, а на крилах - 3 тильного. Наведено оптимальні геометричні розміри зміцнюючих смуг $\mathrm{i}$ їх розташування на лапі, що дозволяє мінімізувати створення локальних напружень і підвищення зносостійкості.

Ключові слова: лапа культиватора, наплавлення, детонаційна шихта, смуги, тепловкладення, модифікування, структуроутворення, нано- та дисперсні алмази. 